\section{False Framings: The Co-opting of Sex-Selection by the Anti- Abortion Movement}

Seema Mohapatra

\section{Introduction}

Sujatha Jesudason and Tracy Weitz provide an empirical examination of the framing of public discourses related to assisted reproductive technology (ART) and abortion by examining two bills considered by the California legislature in "Eggs and Abortion: The Language of Protection in Legislation Regulating Abortion and Egg Donation in Debate over Two California Laws." Jesudason and Weitz analyze the framing of two different legislative efforts: one allowing non-physician practitioners to perform non-surgical abortions and the other removing the prohibition on egg donor payment in the research setting. Jesudason and Weitz identified three different memes that were present in the discussion of these two bills: health care providers and scientists as inherently suspect, denial of women of agency through speaking about them as passive actors that things happen to, and the focus on potential harms and the need to protect women from harm. What was most compelling about their article is that they convincingly show how these themes were used as political tools by both anti-choice and pro-choice groups in California. Jesudason and Weitz note that "frames and language matter."

In this commentary, I build upon this idea to show just how much these frames and language matter by using the example of sex-selective abortion in the United States. The co-opting of woman-protective ${ }^{1}$ framings in the sex-selective abortion discourse has been both very disingenuous and very effective in convincing lawmakers to propose legislation restricting abortion rights for women in many states. What is particularly worrisome about this is that the success has been based on racially charged misconceptions and pseudo-science. Woman-protective ${ }^{2}$ framings in the right context are absolutely appropriate. For example, some sources predict that there will be a surplus of fifteen to twenty percent more men in northwestern India by 2020 than women. ${ }^{3}$ In such a context, Indian feminists are correct to suggest that this disparity harms women and that female fetuses are being harmed. Thus, although women-protective arguments are persuasive, when they are based on false data and racial stereotypes, they need to be refuted passionately so that the truth behind these arguments is revealed and laws based on half-truths are not enacted.

Seema Mohapatra, J.D., M.A., is an Associate Professor of Law at Barry University Dwayne O. Andreas School of Law. She earned her bachelor's degree in Natural Sciences and a minor in Women's Studies at Johns Hopkins University in 1995. She graduated with her Juris Doctor in 2000 from Northwestern University School of Law, after receiving her master's in Public Health in Chronic Disease Epidemiology from Yale University in 1997. 


\section{Legislative Efforts to Ban Sex-Selective Abortion}

Sex-selective abortion, which is also sometimes known as feticide or gendercide, is the "practice of terminating a pregnancy based on the predicted sex of the baby." Eight states have laws prohibiting sex-selective abortion, and 21 states as well as the federal government have proposed such laws since 2009.5 Although that statistic would imply that there is some problem, such as an increase in sex-selective abortion, that these

selection abortion as being culturally okay. And I will suggest to you that we are embracing individuals from some of those cultures in this country, or in this state. And I think that's a good thing that we invite them to come, but I think it's also important that we send a message that this is a state that values life, regardless of its sex." Haggar's comment implies that Asian American populations prefer sons.

However, data shows that there is not a son preference within the Asian population in the United States. ${ }^{9}$ A recent comprehensive report by University of Chicago researchers entitled, "Replacing Myths with Facts: Sex-Selective Abortion Laws in the United States" (which Jesudason edited), found that "foreign born Chinese, Korean, and Indian parents actually have more daughters than white Americans do." ${ }^{\circ}$ The report, which released in the summer of 2014, uses data to dispel the political framings used to propose antisex-selective abortion legislation. This report is extremely helpful as a political tool to ward off false framings because it reveals that political discussions of sex-selective abortion are "steeped in stereotypes that are designed to provide

laws are responding to, there is no evidence of this. In fact, there is a complete lack of proof of the purported "growing trend" of women in the United States having gender-selective driven abortions, as argued by anti-abortion activists. ${ }^{6}$ Yet the language being used by these activists suggests that policymakers need to act immediately to save girls' lives.

\section{Immigrants and the Sex-Selective Abortion Exaggeration}

Anti-abortion proponents have argued that Asian women are moving to America, supposedly bringing with them "cultural biases against having girl children" and are choosing to abort their female fetuses. ${ }^{7}$ If true, such reports would be worrisome and concerning. ${ }^{8}$ However, as described below, such conclusions are actually not based on evidence. That has not stopped anti-abortion activists from using this and other compelling myths as a tool to weaken abortion rights. The anti-abortion movement has adopted the position that female fetuses in the United States are being aborted by immigrants who only want sons. Legislators who have proposed bans on sex-selective abortion have used racially coded language that is harmful and offensive. For example, when lobbying for South Dakota's ban, State Representative Don Haggar stated, "There are cultures that look at a sexan entry-point into banning abortions entirely." ${ }^{11}$ One of the authors of the report, Sital Kalantry, notes that "lawmakers have relied on misinterpretations of narrow data and faulty assumptions about sex selection practices to enact sex-selective abortion bans in the United States." ${ }^{\prime 2}$ Unfortunately, the harmful stereotypes that have led to the proposed bans stigmatize groups, such as Asian Americans. India and China are not the only countries that face imbalanced male-tofemale sex ratios, and male-biased ratios are found in many countries, including those that are predominantly white. ${ }^{13}$ In fact, the highest male-biased sex ratios in the world are Liechtenstein and Armenia."14

Often anti-abortion legislators claim that "abortions based on son preference are widespread in the United States." 15 This analysis is based on old data with a small sample size. ${ }^{16}$ One of the studies that is referenced in state and federal legislative histories is a small study by Dr. Sunita Puri. ${ }^{17}$ In the study, the researchers interviewed 65 recent immigrants in California, New Jersey, and New York, and suggested that $89 \%$ of respondents terminated based on the sex of the fetus. ${ }^{18}$ Representative Franks, in the legislative history of the Prenatal Nondiscrimination Act (PRENDA), states that Puri's study "was an incredibly powerful study." He goes on to say that "sex selection is violence against women, and it is the truest kind of 
war against women, and it has now brought humanity to a place where the three deadliest words on this Earth are 'it's a girl."'19

The implication in several legislative histories of sex selection legislation is that Dr. Puri's study somehow proves that widespread sex selection was occurring in the United States. However, Dr. Puri's study was not a random sample of South Asian women. These women were interviewed because they were specifically seeking sex selection technologies in order to have a son. ${ }^{20}$
Puri's study, "of the 65 women, 51 used ultrasound, 10 used sperm sorting and 4 had undergone in-vitro fertilization for sex determination." ${ }^{27}$ If curbing sex selection was truly the motivation behind these bans, this data could arguably be used to support restrictions on in vitro fertilization, preimplantation genetic identification, and sperm sorting. However, because the activists are actually only concerned about restricting abortion, and not "protecting girls," no solutions regarding ART were offered. In fact, none of the pro-

\section{What is infuriating about the sex-selection ban movement is that the proponents of the ban act as though the primary purpose of the "laws banning sex-selective abortion in the United States is to prevent gender- based discrimination." As Jesudason and Weitz demonstrate, this "women protective" notion is a powerful meme. It is also more politically palatable than revealing that the reason for banning sex-selective abortions is the underlying motivation to restrict access to abortion in general.}

The legislative history in Florida and the House of Representatives misrepresents this study as representative of most South Asian women in the United States. It included only 65 women, "most of whom were recruited from clinics offering elective prenatal ultrasound services." ${ }^{21}$ Additionally, the report contains data that reveals that Asian American families also desire to have daughters. ${ }^{22}$ The report found that after Asian Americans have two boys, their sex ratio at birth is skewed towards females. ${ }^{23}$ Thus the study relied on by proponents of sex-selective abortion bans is at best, incomplete, and at worst, misleading and inappropriate. ${ }^{24}$

\section{Purposeful Focus on Abortion, Not ART}

One of the key "facts" used by sex-selective abortion ban advocates is that there is a male-biased sex ratio at birth for certain ethnic groups within the Asian American community. In actuality, recent national data of sex ratios at birth for foreign-born Chinese, Indians, and Koreans demonstrates that these "groups have more girls overall than white Americans." ${ }^{25}$ Even if there were skewed sex ratios, such ratios "do not provide definitive evidence of sex-selective abortion because sex selection can be conducted through various methods, both prior to conception and prior to implantation of the embryo in the uterus. ${ }^{26}$ In fact, pre-implantation genetic identification is commonly used in assisted reproduction, and parents can decide which embryos to implant based on gender. In Dr. posed or enacted laws that ban sex-selective abortion in the United States prohibit sex selection prior to conception or implantation. ${ }^{28}$ Yet, if these legislators were actually as interested in saving girls as their language suggests, they would not have ignored this area.

\section{The U.S. as an Abortion Destination}

Legislators, who have tried to bring on abortion bans, intimate that " $[\mathrm{t}]$ he United States is one of the few countries in the world that does not ban sex-selective abortion." ${ }^{29}$ PRENDA, a federal bill prohibiting sexselective abortion, proposed to fine or imprison anyone who "perform[ed] an abortion knowing that such abortion is sought based on the sex, gender, color or race of the child." ${ }^{30}$ Although PRENDA did not pass, it was significant as being the first comprehensive proposed federal sex-selection legislation in the United States. Much of the language in justifying the need for PRENDA referenced sex selection as an international problem. Almost half of the findings referenced the worldwide community, other countries' policies, or the cultural practices of foreign countries. The bill also asserted that without this legislation, "the United States was becoming a sort of 'abortion tourism' locale." ${ }^{31}$ In reality, most countries do not ban sexselective abortion. In fact, "[o]nly four countries other than the United States have laws explicitly prohibiting sex-selective abortion: China, Kosovo, Nepal and Vietnam." ${ }^{2}$ Many countries that are concerned about sex selection regulate the practice only by prohibiting 
sex selection through preconception and preimplantation techniques. ${ }^{33}$ This is contrary to the testimony from congressional hearings on PRENDA, which was "centered on the claim that a ban on sex-selective abortion was necessary to conform to international standards." ${ }^{44}$ The text of the earlier bill claimed that "the United States may effectively function as a 'safe haven' for those who seek to have American physicians do what would otherwise be criminal in their home countries." 35

\section{Conclusion}

What is infuriating about the sex-selection ban movement is that the proponents of the ban act as though the primary purpose of the "laws banning sex-selective abortion in the United States is to prevent genderbased discrimination." ${ }^{36}$ As Jesudason and Weitz demonstrate, this "women protective" notion is a powerful meme. It is also more politically palatable than revealing that the reason for banning sex-selective abortions is the underlying motivation to restrict access to abortion in general. ${ }^{37}$ "Save the girls" is a compelling narrative, and proposed bans on sex-selective abortion have tried to take the focus away from abortion and focus on saving women. For example, West Virginia's proposed ban was entitled the "Women's Access to Health Care Act." ${ }^{38}$ However, the bans are all proposed and supported by people who oppose abortion generally," and "politicians who sponsor sex-selective abortion bans are at the forefront of the movement to make abortion illegal." ${ }^{39}$ Pro-choice advocates need to use data, such as that contained in the report, to counter these framings and to reveal the real purpose behind these proposed bans. Co-opting sympathetic pro-woman messaging based on false premises harms women and should not stand unanswered.

\section{Acknowledgement}

Much gratitude to Judith Daar and Kimberly Mutcherson for inviting me to the Intersections workshop and for excellent mentoring and editing and to Kati Haupt for invaluable research assistance.

\section{References}

1. S. Jesudason and T. Weitz, "Eggs and Abortion: The Language of Protection in Legislation Regulating Abortion and Egg Donation in Debate over Two California Laws," Journal of Law, Medicine \& Ethics 43, no. 2 (2015): 259-269.

2. In this commentary, I am using the term "woman-protective" to mean actually saving female fetuses from being destroyed, as this is how it has been raised in the sex-selective abortion context. The term has been used with a different meaning in another context by Reva Siegal. Seigal refers to woman-protective language as language that paternalistically suggests that women need to be protected from their poorly reasoned abortion decisions (which she convincingly argues violates the equal protection clause). See R. Siegel, "The New Politics of Abortion: An Equality Analysis of Woman-Protective Abor- tion Restrictions," University of Illinois Law Review 2007, no. 3 (2007): 991-1053, at 994.

3. S. Kalandry, "Sex Selection in the United States and India: A Contextualist Feminist Approach," UCLA Journal of International Law $\xi$ Foreign Affairs 18, no. 1 (2013): 61-85, at 81.

4. S. Mohapatra, "Global Legal Responses to Prenatal Gender Identification and Sex Selection," Nevada Law Journal 13, no. 3 (2013): 690-721

5. Id.

6. M. Redden, "A New Study Demolishes the Racist Myths Behind Sex-Selective Abortion Bans Surprise! The 'Pro-Women' Bans Are Just Another Way to Block Abortion Rights," Mother Jones, June 4, 2014, available at $<$ m.motherjones.com/politics/2014/06/study-sex-selective-abortion-bans-racist-asianamericans> (last visited April 10, 2015).

7. Id.

8. Unfortunately, sex-selective abortion is a real issue in some countries, such as India. India's government has responded to such actions with the Pre-Natal Diagnostic Techniques (Regulation and Prevention of Misuse) Act (now known as the PreConception and Pre-Natal Diagnostic Techniques (Prohibition of Sex Selection) Act) ("PNDTA") This Act prevents the use of ultrasound or other prenatal techniques to reveal a baby's gender prior to birth. Although it has been in effect for many years, enforcement has been lax. I have argued elsewhere that curbing son-preference by educating girls and enforcing dowry bans may be more effective than PNDTA's bans on gender identification. See Mohapatra, supra note 4, at 715 .

9. Id.

10. The research for the report consisted of (1) conducting desk research; (2) analyzing quantitative data from the American Community Survey (ACS) from 2007 to 2011 and the National Center for Health Statistics (NCHS) from 1979 to 1993; and (3) conducting in-country interviews of physicians, lawyers, government officials, social activists and academics in India. See International Human Rights Clinic at the University of Chicago Law School, National Asian Pacific American Women's Forum, and Advancing New Standards in Reproductive Health, Replacing Myths with Facts: Sex-Selective Abortion Laws in the United States, (June 2014), available at <http:// napawf.org/wp-content/uploads/2014/06/Replacing-Mythswith-Facts-final.pdf> (last visited April 10, 2015)

11. J. Pieklo, "Report Debunks Conservative Case for Sex-Selection Abortion Bans," RH Reality Check, June 4, 2014, available at $<$ rhrealitycheck.org/article/2014/06/04/report-debunks-conservative-case-sex-selection-abortion-bans> (last visited April 10,2015 )

12. Id.

13. International Human Rights Clinic at the University of Chicago Law School, National Asian Pacific American Women's Forum, and Advancing New Standards in Reproductive Health, Replacing Myths with Facts: Sex-Selective Abortion Laws in the United States, (June 2014), available at $<\mathrm{http://}$ napawf.org/wp-content/uploads/2014/06/Replacing-Mythswith-Facts-final.pdf> (last visited September 23, 2014).

14. Id.

15. Id.

16. Id. One of the studies referenced is Douglas Almond and Lena Edlund's study "Son-Biased Sex Ratios in the 2000 United States Census," 105 PNAS 5681, (April 2008) where researchers compared white, Chinese, Korean and Asian Indian birth rates at the first, second, and third child, finding that for second and third children in Chinese, Korean, and Asian Indian families, there appears to be a son preference. The report studies the same question with the newer census data and finds no such son preference, and actually finds Asian families have more daughters than other groups.

17. S. Puri, V. Adams, S. Ivey, and R. Nachtgall, "There Is Such a Thing as Too Many Daughters, but Not Too Many Sons:' A Qualitative Study of Son Preference and Fetal Sex Selection Among Indian Immigrants in the United States," Social Science and Medicine 71, no. 7 (2011): 1170-1172. See Florida Staff 
Analysis, H.B. 1327, (Jan. 25, 2012), Legislative History (House Bill 1327 created Florida's proposed sex-selective abortion ban, the "Susan B. Anthony and Frederick Douglass Prenatal Nondiscrimination and Equal Opportunity for Life Act"). See also 158 Cong. Rec. H3180-08 (May 30, 2012) (statement of Rep. Franks); H.R. REP. 112-496, H.R. Rep. No. 496, 112TH Cong., 2ND Sess. 2012, 2012 WL 1939420 (Leg. Hist.) (PRENATAL. NONDISCRIMINATION ACT (PRENDA) OF 2012).

18. Id.

19. 158 Cong. Rec. H3180-08 (May 30, 2012) (statement of Rep. Franks).

20. International Human Rights Clinic at the University of Chicago Law School, National Asian Pacific American Women's Forum, and Advancing New Standards in Reproductive Health, Replacing Myths with Facts: Sex-Selective Abortion Laws in the United States (June 2014), available at <http:// napawf.org/wp-content/uploads/2014/06/Replacing-Mythswith-Facts-final.pdf > (last visited April 10, 2015) (hereinafter cited as International Human Rights Clinic).
21. $I d$.

22. Id.

23. $I d$.

24. Id.

25. $I d$.

26. $I d$.

27. $I d$.

28. Id.

29. Id.

30. See Mohapatra, supra note 4 , at 711 .

31. $I d$.

32. See International Human Rights Clinic, supra note 20.

33. Id.

34. Id.

35. Id.

36. Id.

37. Id.

38. S.B 43, 81st Leg., Reg. Sess. (W. Va. 2013).

39. See International Human Rights Clinic, supra note 20. 